\title{
Police officers as victims
}

\section{Sentencing standards and their justifications in England and Germany}

\author{
Prof Dr Osman Isfen, Ruhr-University Bochum
}

Dr Regina E Rauxloh, University of Southampton ${ }^{1}$

\section{Abstract}

While there is plenty research in crime committed by police officers surprisingly little debate can be found regarding the situation where a police officer becomes a victim. This is remarkable as the police not only embody criminal law enforcement but also epitomises State power. Based on a comparative study, this article examines how criminal law in England and Germany deals with attacks against police officers through separate criminal offences as well as increased sentences. The authors examine how the use of criminal law reflects on the State's perception and valuation of the role of the police officer. It will be shown that while in England there is the clear understanding that the status of the victim as police officer has an aggravating effect, Germany strongly opposes the idea that the office-holder deserves more protection than ordinary citizens. On the contrary, the law takes in consideration that the offender finds him- or herself in a vulnerable situation when faced with the power of the State.

Keywords

Police officers as victims, resistance against law enforcement, sentencing standards, comparison England and Germany, mitigating and aggravating circumstances

\section{Introduction}

In the context of criminal law, law enforcement is usually associated with the role of the police in protecting the victim of crime, but one easily forgets that quite often police officers themselves become the victim of crime. Interestingly, while crimes committed by police officers are subject to extensive research and debate, violence against police officers rarely appears in literature, legislation or case law. It is only in recent years that there has been empirical research into the extent of violent attacks against police officers. For example, the German state of Bavaria compiled its first statistics regarding violence against police officers as late as 2011 . This data records 13,000 cases of assault and insults against police officers in one year alone. As many as 1,680 officers were injured, 13 of whom suffered serious harm. Data provided by the Police Union in North-Rhine Westphalia indicates that numbers are rising with incidents of assaults increasing in 2013 by 500 to 7092 and the number of victimised police officers from 10,831 to nearly $12,000 .^{2}$ From these police officers, 1,800 were injured and six of whom suffered serious injuries. ${ }^{3}$ The head of the Police Union in Nord-Rhine Westphalia, Arnold Plickert explained that in many cases just the arrival of a

\footnotetext{
${ }^{1}$ Prof. Dr. Osman Isfen is Professor at the Ruhr-University Bochum, Germany. Dr Regina E Rauxloh is Associated Professor at the University of Southampton, UK.

${ }^{2}$ K. Frigelj, 'Wo Beamte Zielscheiben in Uniform sind' Die Welt 15 April 2014 available at http://www.welt.de/politik/deutschland/article126959656/Wo-Beamte-Zielscheiben-in-Uniform-sind.html (last visited 12 September 2015).

${ }^{3}$ Ibid. This trend is confirmed for the whole of Germany by the numbers of the German Federal Criminal Police Office statistics (Bundeskriminalamt, Polizeiliche Kriminalstatsisik) available at http://www.bka.de/DE/Publikationen/PolizeilicheKriminalstatistik/2013/2013Standardtabellen/pks2013Standardtabelle nOpferUebersicht.html. (last visited 12 September 2015).
} 
uniformed officer is enough to prompt an attack. ${ }^{4}$ Whilst other data suggests a slow decrease of violent attacks against police officers in $2013^{5}$, the total number is still shockingly high. The German Federal Criminal Police Office (Bundeskriminalamt) counted 6,200 officers as victims of crime in 2014, an increase of 6.3\% within one year. ${ }^{6}$ Head of the Baden Wurttemberg Police Union, Rüdiger Seidenspinner estimated that at least two police officers are injured every day. ${ }^{7}$ In England and $W_{a l e s}{ }^{8}$, recent information provided by Police Minister Mike Penning (in response to a question from Labour MP Andrew Gwynne) revealed that 18,882 officers have been assaulted on duty over the last three years. This data has however been strongly criticised by PoliceOracle.com, who claims that the number of assaults were actually as high as 32,864. Unfortunately, there is currently no agency recording the overall assaults on police officers in England. ${ }^{9}$

At the same time, the police not only embody criminal law enforcement but also epitomises State power. Thus, the role of the police officer as a subject to an attack has a political meaning that goes beyond the traditional objectives of criminal law. The aim of this article is to shed light on how the use of criminal law as the harshest response of the State to an infringement of its norms reflects on the State's perception and valuation of the role of the police officer. ${ }^{10}$

Based on a comparative study between England and Germany, this article addresses the question of how criminal law deals with attacks against police officers through separate criminal offences as well as increased sentences. It examines how the State uses criminal law as a means to deal with attacks against police officers (as a person situated in a dangerous situation as well as in their function of representatives of the State). The authors will look at three aspects of crimes committed against police officers. First, both England and Germany have specific offences regarding resistance against law enforcers which we will analyse in Section 2. With regards to Germany, the article will focus on the recent landmark decision of the German Federal Supreme Court regarding the prohibition of double counting. Second, Section 3 will examine non-lethal attacks on police officers, which are not criminalised as separate offences in England nor Germany but where the status of the victim as office-holder might be reflected at the sentencing stage. Thirdly, Section 4 looks at the law of homicide and analysis of how the killing of police officers is treated at the sentencing stage, especially the regarding the sentencing tariff in England. The final section discusses what the regulation of attacks against police officer reveals about the value statement the two legal systems are making about the protection of police officers. ${ }^{11}$

\section{Resistance against Law Enforcement}

Both England and Germany have statutory provisions stemming from the $19^{\text {th }}$ century which explicitly deal with cases where the offender resists the execution of an enforcement officer's

\footnotetext{
${ }^{4}$ See Frigelj, above n. 2.

${ }^{5}$ C. Cornelius, 'Gewerkschaften fordern einen ernsteren Umgang ' Die Welt 6 March 2014, available at http://www.welt.de/regionales/stuttgart/article125519274/Gewerkschaften-fordern-einen-ernsteren-Umgang.html. (last visited 12 September 2015).

${ }^{6}$ dpa, Mehr Angriffe auf Polizisten - Innenminister fordert abermals Schutzparagrafen, Frankfurter Allgemeine 4 August 2015.

${ }^{7}$ See Cornelius, above n. 5.

${ }^{8}$ Hereafter referred to England.

${ }^{9}$ WestYorkshire Polcie Federation 'Home Office under records police officer assault figures' available at http://www.wypf.polfed.org/2014/09/25/home-office-under-records-police-officer-assault-figures/ (last visited October 2015).

${ }^{10}$ Of course this is only one aspect of the picture and other related questions such as funding, organisation, control etc. of the police need to be studied in other research projects.

${ }^{11}$ Although different legal rules in deal with different office-holders, this article focuses exclusively on police officers.
} 
duties. Of course in most cases the enforcement officer is a police officer and the act of law execution is making an arrest.

\section{Situation in England}

The most specific criminal offence in English law is s38 Offences against the Person Act (OAPA) 1861 which reads:

Whosoever shall assault any person with intent to resist or prevent the lawful apprehension or detainer of himself or of any other person for any offence, shall be guilty of a misdemeanor, and being convicted thereof shall be liable, at the discretion of the court, to be imprisoned for any term not exceeding two years. ${ }^{12}$

The core of this offence is the resistance against the arrest rather than the causation of harm. ${ }^{13}$ The harm element can be fulfilled by acts as small as spitting, or pushing and shoving during the resistance. If more than minor physical harm is caused, the offender will be charged instead with actual bodily harm (ABH) or grievous bodily harm (GBH). ${ }^{14}$ The Sentencing Council explains:

The additional element of intent in this offence relates to the attempt to resist arrest and involves an inherent aggravating factor not present in the offence of common assault in that the victim (whether a police officer or a member of the public carrying out a citizen's arrest) was performing a public service. $^{15}$

S38 OAPA 1861 prescribes a maximum sentence of 24 months imprisonment and/or an unlimited fine. ${ }^{16}$ However, the sentencing guidelines of 2008 envisioned a lower sentence range up to only 18 months. ${ }^{17}$ The new sentencing guidelines of 2011 lowered the sentence for this offence further still: even for the highest category ${ }^{18}$ the range is now only 12 to 51 weeks custody, thus less than 12 months. Not surprisingly, the public response to the Sentencing Council consultation showed concern with the lenient sentences for this offence. ${ }^{19}$ The Sentencing Council emphasised however that the sentence for s38 OAPA 1861 needed to be proportionate with common law assault, as the harm inflicted on the victim was the same in both offences. ${ }^{20}$ Thus, the Council focussed on

\footnotetext{
12 The victim does not necessarily have to be a police officer but any person carrying out a public service, for example a store security officer. Sentencing Council Assault Guideline Public Consultation available at https://www.sentencingcouncil.org.uk/wp-content/uploads/ASSAULT_Public_web.pdf (last visited 12 September 2015) at 16.

${ }^{13}$ Sentencing Guidelines Council, Assault and other offences against the person - Definitive Guideline 2008 at 18. ${ }^{14}$ Ibid.

${ }^{15}$ Ibid. Likewise the CPS explains: "When a police officer is assaulted, a charge under section 89(1) of the Police Act 1996 will usually be more appropriate unless there is clear evidence of an intent to resist apprehension or prevent detention and the sentencing powers available under section 89(1) or for Common Assault are inadequate. This will rarely be the case when injuries are minor and inflicted in the context of a struggle.” Offences against the Person, incorporating the Charging Standard, available at http://www.cps.gov.uk/legal/l_to_o/offences_against_the_person/\#a14 (last visited 12 September 2015).

${ }^{16}$ Sentencing Guidelines Council, above n. 13, at 16.

${ }^{17}$ Under the previous guidelines the starting point was 36 weeks and the range between 24 weeks and 18 months.

${ }^{18}$ Unlike in Germany, in England and Wales the Sentencing Council has set out very specific sentencing guidelines in the 'Assault Definite Guideline', which divide each offence into three different categories, reflecting three levels of seriousness. Each category has a starting point, from which the sentence sets out when considering mitigating or aggravating circumstances and a sentencing range. This sentence range is in addition to the statutory maximum sentence of the relevant offence.

${ }^{19}$ Sentencing Council, Assault Guidelines - Response to Consultation 2011 available at

https://www.sentencingcouncil.org.uk/wp-content/uploads/Assault_guideline_-_Response_to_the_consultation.pdf (last visited 12 September 2015) at 13.

${ }^{20}$ Ibid. In the Sentencing Council Assault Guideline Professional Consultation the Sentencing Council states that "The proposed offence ranges and starting points, which are higher than those for common assault but lower than those in the
} 
the harm suffered by the victim rather than the core of the offence, namely the resistance against the arrest (and thus against state power). The resistance element no longer seems to be considered to be grave enough to be reflected in the sentence. If the attack against the office (in addition to the person of the officer) is not reflected in the sentence, this begs the question as to why there are two separate offences of s38 OAPA 1861 and common law assault. If one argues that the different labelling is sufficient, one overlooks that initially the legislator had also attached a quite substantial sentence of two years. It seems that the Sentencing Council has overruled this clear value statement.

The more general offence in relation to attacks against office-holders in England is assault on a police constable in execution of his duty. S89(1) Police Act 1996 reads:

Any person who assaults a constable in the execution of his duty, or a person assisting a constable in the execution of his duty, shall be guilty of an offence and liable on summary conviction to imprisonment for a term not exceeding six months or to a fine not exceeding level 5 on the standard scale, or to both.

This provision is used where the intent to resist an arrest cannot be proven. ${ }^{21}$ Like s38 OAPA 1861, this offence too, covers cases where only minor or no harm at all is caused and again the Sentencing Guideline prescribes that "where the injuries suffered are serious enough, the offence will fall under ABH."22 Where no harm at all is caused, the offences of resistance and obstruction according to s89(2) applies. Having a lower mens rea threshold, it is not surprising that the statutory sentence for s89 Police Act 1996 is much lower than the two years for s38 OAPA1861. The maximum sentence provided in s89 Police Act 1996 is six months’ imprisonment and/or a fine.

\section{Situation in Germany}

In Germany, the main provision which explicitly considers the status of the victim as an officeholder is $\$ 113$ Strafgesetzbuch $(\mathrm{StGB}),{ }^{23}$ resistance against enforcement officers. This provision reads:

Whosoever, by force or threat of force, offers resistance to or attacks a public official or soldier of the Armed Forces charged with the enforcement of laws, ordinances, judgments, judicial decisions or orders acting in the execution of such official duty shall be liable to imprisonment not exceeding three years or a fine. ${ }^{24}$

Over a third of offences committed against a police officer are resistance against enforcement officers. ${ }^{25}$ Until recently, $\$ 113$ had the same maximum sentence as in England, namely two years' imprisonment. Like England's, the German sentencing regime was also amended in 2011 but here

current guideline, reflect the Council's aim for proportionality.” Sentencing Council Assault Guideline Professional Consultation available at https://www.sentencingcouncil.org.uk/wp-content/uploads/ASSAULT_Professional_web.pdf (last visited 12 September 2015) at 26.

${ }^{21}$ The CPS charging guideline explains: „When a police officer is assaulted, a charge under section 89(1) of the Police Act 1996 will usually be more appropriate unless there is clear evidence of an intent to resist apprehension or prevent detention and the sentencing powers available under section 89(1) or for Common Assault are inadequate.” Above, n. 15.

${ }^{22}$ See Sentencing Council Assault Guideline Professional Consultation, above n. 20, at 8.

${ }^{23}$ German Penal Code, hereinafter Called StGB. All § without further indications are those of the StGB.

${ }^{24}$ Another provision which considers the status of the victim as an office holder, but not specifically that of a police officer is $\S 121$ I Nr. 2 (prisoner-mutiny). Otherwise, the victimhood of the office holder only plays a role in matters of certain application procedures ( $\S \S 77 a$ I, 194 III).

${ }^{25}$ See dpa, above n. 6. 
the sentence was increased from two to three years rather than lowered as in England. ${ }^{26}$ The original maximum sentence of two years had been intentionally set one year lower than the maximum penalty for the more general offence of coercion (using threats or force to cause a person to do, suffer or omit an act) according to §240I. ${ }^{27}$

The actus reus in $\S 113$ is similar to $\S 240$ in that the offender tries to coerce the office holder by force or threat of force to omit the intended act of law enforcement. This pre-2011 sentence discrepancy was based on the recognition that the coercion in a situation when facing an arrest (or other law enforcement directed against oneself) was likely to cause a "state of excitation" in the offender. ${ }^{28}$ This special situation was considered to require not only a separate offence but also a sentence that actually privileged the offender, who finds him or herself face-to-face with law enforcement. ${ }^{29}$ While one might think this emphasis on protection not of but from state power reflects the experience of State oppression in Nazi Germany, one has to keep in mind that §113 was introduced in 1872. The sentencing privilege in $\$ 113$ was however abolished in 2011 when the sentence was raised to two years and thus brought to the same level as the general offence of coercion, §240. Thus, in both criminal justice systems sentencing for resistance against the police has been brought in line with general offences. It seems that the fact that a representative of the State was attacked has lost its distinguishing effect, both as aggravating fact, as previously in England, and mitigating fact, as previously in Germany. Two points of interest regarding the situation in Germany: first the academic debate regarding the precise purpose of $\S 113$ and second the sentencing practice.

a) Double protective purpose?

Unlike in England, the precise purpose of $\S 113$ subject of discussion among German scholars. The present authors argue that the aim of this offence is to protect not only the execution of the office but also the officer themselves; the so called double protective purpose (Doppelter Schutzzweck). ${ }^{30}$ Firstly, it has to be remembered that the citizen is under the general obligation to accept and tolerate any lawful enforcement of state power. Thus, the primary purpose of $\S 113$ is to sanction any violation of this citizens duty. This interpretation is supported by a systematic consideration of the position of $\S 113$ in the system of the German Penal Code ${ }^{31}$ as it is located in Chapter 6 of the Code, titled "Resistance against State Authority". This position can only mean that the protection of the law enforcement beyond the law enforcer is the principal aim. ${ }^{32}$

At the same time a systematic interpretation of the provision shows clearly that in addition to the protection of law enforcement $\S 113$ also protects the bodies who are called on to implement the

\footnotetext{
${ }^{26}$ At the same time the protection was extended to include more victim categories, namely fire fighters and rescue forces.

${ }^{27} \S 240$ reads: „Whosoever unlawfully with force or threat of serious harm causes a person to commit, suffer or omit an act shall be liable to imprisonment not exceeding three years or a fine.”

${ }^{28}$ H. Rosenau in: H. Laufhütte, K. Tiedemann and R. Rissing van Saan (eds), Leipziger Kommentar StGB 12th edn (Vol 5 Berlin, New York De Gruyter 2009) §113, Rn 5; S. Messer, 'Widerstand sinnvoll? Stellungnahme zum Gesetzesentwurf zur Änderung des § 113 StGB’ (2011) 1 Neue Kriminalpolitik 1.

${ }^{29}$ In the original Code of 1871 the offence of resistance against a state official under $\S 113$ was however two years compared to only one year for coercion under $§ 240$.

${ }^{30}$ A. Eser in: A. Schönke and H. Schröder, Strafgesetzbuch 29th edn (C.H. Beck Verlag: Munich 2014 ) §113Rn2.

${ }^{31}$ German rules on statutory interpretation include 'systematic interpretation' which purport that a statute is organised in an intentional and systematic way so that meaning of a provision can be drawn from its position in the overall system of the statute.

${ }^{32}$ N. Bosch in: W. Joecks and K. Miebach (eds) Münchener Kommentar zum Strafgesetzbuch 2nd edn (Vol 2 and 3 , C.H. Beck Verlag: Munich 2012) § 113 Rn 1.
} 
actions of law enforcement. First of all, the two forms of actus reus listed in $§ 113$ I, namely resistance and attacks of public official, are listed alternatively not cumulatively. ${ }^{33}$ The criminal element of an attack of a public official does not require impairment of the law enforcement action or even the intention to impair the law enforcement. This can only be understood to show that the executing officer is protected, even in cases where the action of the law enforcement itself is not threatened. Furthermore, §114III extend the protection of \$113 I "to members of the fire brigade, the emergency services or of a rescue service who are lending assistance” even though these bodies are usually not engaging in activities of law enforcement. Consequently §114III does not mention the element of resistance against law enforcement but only mentions the rescue activity. Rather than law enforcement it is the individual person of the rescuer who is protected. These considerations speak clearly for a double protective purpose of the provision.

On the other hand, there are scholars who argue that $\$ 113$ exclusively protects enforcement activities of the State and that the officer is only protected by the general non-fatal offences in $\S \S$ 223ff (offences against the person) under $\S 240$ (coercion). ${ }^{34}$ Bosch for example argues that $\S 113$ has to have a different protective function to be distinguished from the general offences against the person. This is true especially with regards to coercion under §240, the purpose of which is to protect the freedom of the will of the individual. Bosch reasons that if $\$ 113$ included protection of the individual officer, this would lead to the result that the protection of the free will of the individual (normally protected under the general norm of §240) would be completely covered by the special offence of $\S 113$, which is designed to protect the implementation of the will of the State. This in turn would mean that the officer is seen as a mere tool of the State, whose individual free will is not worth separate protection. ${ }^{35}$ This argument was warranted before the 2011 law reform brought the sentence of $\S 113$ in line with $\S 240$. Until then, one could argue that it was contradictory to offer extra protection to the officer in a special norm, which at the same time prescribed a sentence a third lower than the general protection of $§ 240$. Since the law reform in 2011, which equalised the sentence in both norms, this argument is obsolete. ${ }^{36}$

Another argument which is raised against the double purpose is the fact that $\$ 113$ excludes criminal liability where the defendant mistakenly believes that the act of law enforcement is unlawful (§113 III). ${ }^{37}$ Even if this mistake had been avoidable it still counts as a mitigating factor at sentencing stage. ${ }^{38}$ This difference to $§ 240$, which does not consider any mistakes by the offender, can however be an explained by a different reason. The legislator introduced separate offences for the special protection of police officers because these cases are very complex conflict situations, which include multifaceted interactions between police and citizens. In many cases both sides use

\footnotetext{
33 "Whosoever, by force or threat of force, offers resistance to or attacks a public official” emphasis added.

${ }^{34}$ See Bosch, above n. 32, § 113 Rd. 2.

35 Ibid at $\S 113$ Rn 1.

${ }^{36}$ C. Fahl, 'Ist $\$ 113$ StGB i.V.m. § 114 StGB (noch) eine Privilegierung?` (2012) 124 Zeitschrift für die gesamte Strafrechtswissenschaft, 316, 320; M. Zöller, 'Neue Straftatbestände zum Schutz vor Gewalt gegen Polizeibeamte?` (2015) Zeitschrift internationale Strafrechtsdogmatik 445.

${ }^{37}$ (3) The offence shall not be punishable under this provision if the official act is unlawful. This shall also apply if the offender mistakenly assumes that the official act is lawful.

${ }^{38}$ (4) If the offender during the commission of the offence mistakenly assumes that the official act is unlawful and if he could have avoided the mistake the court may mitigate the sentence in its discretion (section 49(2)) or order a discharge under this provision if the offender's guilt is of a minor nature. If the offender could not have avoided the mistake and under the circumstances known to him he could not have been expected to use legal remedies to defend himself against the presumed unlawful official act, the offence shall not be punishable under this provision; if the use of remedies could have been expected the court may mitigate the sentence in its discretion (section 49(2)) or order a discharge under this provision.
} 
violence. To reflect this special situation the legislator introduced regulations about mistakes which favour the defendant. The legislator was mindful that the defendant in the heat of the moment might very well wrongly assume that the law enforcer acts ultra vires, even though he could have avoided this mistake. Even after the equalisation of the penalty the special offence of $\S 113$ still makes allowance for the special situation of the defendant and privileges him if he mistakenly assumed unlawful behaviour. The reason for this favourable regulation is however that the legislator recognises that citizens might overreact in the heat of the moment when faced with state power and thus does not contradict the theory of double protective purpose. Instead, the legislator tries to find a balance between the interests of office, officer and citizen, a balance which requires special considerations which the general offence of coercion does not provide. Thus in view of both points, namely the inclusion of the assault (independent from resistance against law enforcement) and the extension of the protection to rescuers outside law enforcement, it must be concluded that $\S 113$ protects both law enforcement as well as the acting officer. ${ }^{39}$ Our conclusion is in line with the interpretation of the Federal Constitutional Court which stated even before the law reform:

By criminalising the use of force or the threat of force when resisting law enforcement (§113), the legal protection of officials who are exposed to special risks during enforcement action by opposition, should be strengthened. ${ }^{40}$

\section{b) Aggravating circumstance?}

A particular important question in Germany is whether in practice judges ascribe an aggravating effect to the special status of the victim and therefore punish a violent attack harsher when a violent attack has been committed with the victim being a law enforcement officer. Interestingly, like in England, there is surprisingly little published case law discussing this aspect in Germany. One point which was recently discussed by the German Federal Court, ${ }^{41}$ was the question of the relationship between the definition of the offence and justifications for sentence aggravation. In Germany, §46 III lays down the general principle that circumstances, which fall under the mens rea or actus reus of the criminal offence must not be considered again at sentencing stage. The violation of the value protected in the offence (for example protection of human life) as such, is covered by the envisioned regular sentence and does not justify further sentence increase. For example, the fact that the offender acted „with the absolute inhuman will of destruction” during the killing of his victim, cannot be considered as an aggravating factor, because this aspect merely describes the necessary mens rea for murder, namely the intent to kill. ${ }^{42}$ The same applies to the debate whether an aggravated sentence is justified where the offender did not rescind from the attempt, although he had the opportunity to do so. Where the offender is tried for the complete offence rather than the inchoate crime of attempt, completion is covered by the charged offence and the failure to withdraw from the attempt cannot be considered as an additional aggravating factor. ${ }^{43}$ This so-called prohibition of double counting ${ }^{44}$ is generally not contested in either Germany or England. ${ }^{45}$ In

\footnotetext{
${ }^{39}$ T. Singelstein and J. Puschke, 'Polizei, Gewalt und das Strafrecht - Zu den Änderungen beim Widerstand gegen Vollstreckungsbeamte‘ (2011) Neue Juristische Wochenschrift NJW 3473, 3474.

${ }^{40}$ Bundesverfassungsgericht, Neue Zeitschrift für Verwaltungsrecht 2007, 1181.

${ }^{41}$ Bundesgerichtshof.

${ }^{42}$ Bundesgerichtshof Höchstrichterliche Rechtsprechung im Strafrecht 2007 Nr. 15. Compare also BGH Neue Zeitschrift für Strafrecht 2009, 564.

${ }^{43}$ G. Schäfer, G. Sander and G. van Gemmeren (eds) Praxis der Strafzumessung 5th edn (C.H.Beck Verlag: Munich 2012) Rn 692. For relevant case law see for example BGH Neue Zeitschrift für Strafrecht 1983, 217f.; Neue Zeitschrift für Strafrecht-Rechtsprechungsreport 2003, 41 and 2007, 194.

${ }^{44}$ Doppelverwertungsverbot.
} 
English law the Sentencing Council makes it clear that:

"...factors (such as the vulnerability of victims or abuse of trust) [...] are integral features of certain offences $[\ldots]$ the presence of the aggravating factor is already reflected in the penalty for the offence and cannot be used as justification for increasing the sentence further." (original emphasis) ${ }^{46}$

Regarding assaults on police officers, this principle was confirmed in Germany in the latest landmark case of the Federal Supreme Court, ${ }^{47}$ which declared that where the status of the victim is already ascertained by the elements of the crime, there is no further aspect of wrongdoing beyond the commission of the crime, which could be considered at the sentencing stage. In other words, the wrongdoing of assaulting the police officers is covered in the definition of the offence so that no punishment beyond the statutory sentence can be justified.

In this case, the defendant had participated in a demonstration in Bonn against a campaign rally of the political party „Pro NRW”. The situation led to serious violent clashes for which the police were obviously not sufficiently prepared. Together with other demonstrators the defendant threw stones and other objects at police officers, who were deployed in order to barricade a crossroad. Later he pulled out a knife and approached the officers. Initially he stabbed in the direction of the thigh of an officer, who was involved in a dispute with other participants of the demonstration, but fortunately the officer was able to repel the stab. The defendant then made towards another police officer, who was a member of the squad for preservation of evidence and was filming the situation. The defendant stabbed him in the left thigh and started throwing stones at other police officers standing close by. When a police officer tried to force him back he stabbed her in both thighs and caused two cuts of ten and three centimetres respectively. The District Court Bonn found the defendant guilty of aggravated breach of peace, grievous bodily harm and resistance against a police officer and sentenced him to six years imprisonment.

At the appeal, the Federal Supreme Court confirmed the conviction but rejected the sentence. The Court not only criticised the lower court for being rather brief in its justification for the long sentence but also found fault with the sentencing decision itself for three substantive reasons. First, the Court held that the argument stating the assaults were directed against 'representatives of the state' contravenes the prohibition of double counting ${ }^{48}$ as it already formed elements of the offence of $\S 113$. Secondly, it criticised the value system of the lower Court. It argued that there is no reason that in the context of breach of the peace, violence against innocent bystanders would be less blameworthy than violence against police officers. ${ }^{49}$ The main reason for overturning the lower court's sentence was however, that the lower court had justified an increase of penalty with the fact that the victims had in no way provoked the attack or given any cause for the assaults. The defendant's claim that the officers had provoked the attack by forcefully vacating the area was

\footnotetext{
${ }^{45}$ K. Miebach in: W. Joecks and K. Miebach (eds) Münchener Kommentar zum Strafgesetzbuch 2nd edn (Vol 2 and 3 , C.H. Beck Verlag: Munich 2012) § 46 Rd. 183. There are however a number of decisions where the prohibition of double counting was not respeced, W. Theune, 'Grundsätze und Einzelfragen der Strafzumessung - aus der Rechtsprechung des Bundesgerichtshofs (Teil I)` (1985) Der Strafverteidiger 205.

46 The Sentencing Guidelines Council, Guideline “Overarching Principles: Seriousness” available at https://www.sentencingcouncil.org.uk/wp-content/uploads/web_seriousness_guideline.pdf (last visited 12 September 2015) at 6.

${ }^{47}$ BGH Neue Zeitschrift für Strafrecht-Rechtsprechungsreport 2014, 45. See O. Isfen, 'Der "Repräsentant des Staates" als Opfer der Straftat - Strafschärfend, strafmildernd oder unrechts- und schuldneutral?’ (2014) Höchstrichterliche Rechtsprechung im Strafrecht 88.

48 §46 Abs. 3.

${ }^{49}$ BGH Neue Zeitschrift für Strafrecht-Rechtsprechungsreport 2014, 46.
} 
rejected at trial because this was not sufficient reason to attack officers with a knife. The lower Court had justified the sentence increase therefore with the argument that the defendant could have refrained from his acts because there was no reasonable or understandable ground for a knife attack. In the end however, this is only a lack of a mitigating factor, not an aggravating circumstance. ${ }^{50}$ The Federal Supreme Court made it clear that the fact that the offence was committed in the first place cannot be considered again at the sentencing stage as aggravating factor. ${ }^{51}$

In spite of these numerous reasons given by the Federal Supreme Court, the new trial in front of a different chamber of the District Court Bonn did not come to a different result. In January 2014, the six year prison sentence of the accused was confirmed with the justification that the defendant adhered to his acts and rather than showing remorse demonstrated his hostile attitude towards law and remained prepared to use violence to this day. Although the sentence had not been changed the Supreme Court's decision is valuable for clarifying the sentencing position in cases of attacks against police officers.

\section{Assault}

\section{Causing Bodily Harm in England and Wales}

In England, where more than minor harm is caused in the attack, the general provisions of causing actual bodily harm (ABH), s47 OAPA1861 or grievous bodily harm (GBH) ss18, 20 OAPA 1861 apply. There is no separate offence of causing $\mathrm{ABH}$ or $\mathrm{GBH}$ where the victim is a police officer on duty, nor do the sentencing guidelines provide for a distinction in these cases. Indeed, notwithstanding the very detailed structure, neither the previous guidelines by the Sentencing Guidelines Council nor the current guidelines by the Sentencing Council ${ }^{52}$ mention at any point that an attack on a police officer is considered a special factor. The Sentencing Council in their Guideline 'Overarching Principles: Seriousness' ${ }^{53}$ explains that the lists of aggravating and mitigating factors "are not intended to be comprehensive and the aggravating factors are not listed in any particular order of priority." 54 Nevertheless, it is surprising that these long lists do not make any reference to an aggravating factor if the victim is police officer. The closest the guidelines come is that the list of "factors indicating a more than usually serious degree of harm" includes the case where the offence "is committed against those working in the public sector or providing a service to the public". ${ }^{55}$ This group is however much wider than the police force and includes, for example, teachers and nurses.

Astonishingly, it is only in their resource assessment rather than in the sentencing guidelines that the Sentencing Council declares that "it must be emphasized that, in every case where even modest injury resulted, the appropriate offence is assault occasioning actual bodily harm, the seriousness of which would be increased if it involved a police officer." 56 This principle, although hidden in the resource assessment, seems to reflect standard sentencing practice in England. It is generally accepted that such attacks, if charged, will be prone to harsher sentences when committed against a

\footnotetext{
${ }^{50}$ Ibid.

${ }^{51}$ Ibid.

${ }^{52}$ Which replaced the Sentencing Guidelines Council in April 2010.

53 This Guideline was issued by the predecessor the now abolished Sentencing Guidelines Council in 2004 but is still in place until the Sentencing Council replaces it with a new guideline.

${ }^{54}$ Sentencing Guidelines Council, above n. 45.

55 Ibid at 7.

${ }^{56}$ Sentencing Council: https://www.sentencingcouncil.org.uk/news/item/sentencing-council-launches-new-definitiveguideline-for-assault-offences-2/ (last visited 12 September 2015)
} 
police officer rather than an ordinary citizen. In $R v$ Colin Dickson ${ }^{57}$ the Court of Appeal declared that assaults on police officers:

“...are, of course, particularly grave, and we agree with the learned judge that any attack on a police officer who is carrying out his duty has to be treated very seriously." ${ }^{, 58}$ (emphasis added)

There is also a general understanding that where the victim is a police officer, a non-custodial sentence should become a custodial one. ${ }^{59}$ As far as the authors of this article are aware, this assumption is not contested either in literature or the media. It is therefore interesting that neither statute nor the very detailed sentencing guidelines prescribe for any such aggravation.

\section{Causing Bodily Harm in Germany}

In German penal law, apart from a few exceptions, ${ }^{60}$ the position as office-holder is only relevant for offences in which the crime is not committed against but by the office holder. ${ }^{61}$ Thus, like in England, where a police officer subject to an attack, only the general offences apply, which protect against actual bodily harm, coercion or insult. The question is then whether the status of the victim as police officer is considered at the sentencing stage.

Unlike in England, the German criminal justice system does not have an institution comparable to the English Sentencing Council. Nor are there general sentencing provisions, other than the general $\$ 46$ which reads:

\section{Principles of sentencing}

(1) The guilt of the offender is the basis for sentencing. The effects which the sentence can be expected to have on the offender's future life in society shall be taken into account.

(2) When sentencing the court shall weigh the circumstances in favour of and against the offender.

Consideration shall in particular be given to

the motives and aims of the offender;

the attitude reflected in the offence and the degree of force of will

involved in its commission;

the degree of the violation of the offender's duties;

the modus operandi and the consequences caused by the offence to the

extent that the offender is to blame for them;

the offender's prior history, his personal and financial circumstances;

his conduct after the offence, particularly his efforts to make restitution

\footnotetext{
57 [2005] EWCA Crim 1826.

58 Per Justice Ellias, para 12.

${ }^{59}$ D.A. Thomas, Principles of Sentencing - The Sentencing Policy of the Court of Appeal Criminal Division 2nd edn (Heinemann Educational: London 1979) 106.

${ }^{60}$ In the German penal code, the office holder as victim of a crime first appears in the field of jurisdiction: according to $\S 5 \mathrm{Nr} .14$ German penal law is valid, regardless of the crime scene's law, also for crimes which are committed abroad, if these are committed against an office holder, a person who is particularly obligated in public service or a soldier of the German armed forces in the exercise or in relation to their duties. Furthermore, the office holder as explicit object of an assault can be found - beside the "classic" offences of state protection, which also naturally protect selected representatives of the state, like for example $\S 106$ (coercion of the Federal President and other members of a constitutional body) - especially in $\S 113$ (resistance against enforcement officers) and § 121 I Nr. 2 (prisoner-mutiny). Moreover, the victimhood of the office holder only plays a role in matters of application (§£ 77a I, 194 III).

${ }^{61}$ E.g. $\S \S 240$ IV Nr. 3 (Using threats or force to cause a person to do, suffer or omit an act by abusing his powers or position as a public official), 258a (Assistance in avoiding prosecution or punishment given in official capacity) or $\S 340$ (Causing bodily harm while exercising a public office).
} 
for the harm caused as well as the offender's efforts at reconciliation with the victim.

(3) Circumstances which are already statutory elements of the offence must not be considered. ${ }^{62}$

In addition to §46, a few specific case groups can be found in the Penal Code which include aggravating or mitigating circumstances, such as murder under mitigating circumstances (§213) or aggravated theft (§243). While overarching sentencing principles with general application beyond $\S 46$ are not known to the German sentencing system, the judiciary has developed sentencing principles for some specific case groups. Could German courts develop such a case group regarding cases where the victim is a police officer? To answer this, one needs to distinguish whether the attacked office-holder was acting lawfully or unlawfully when executing their authority.

In the first scenario, the assault might have taken place in a situation where the office-holders did not act in execution of their authority at all (e.g. attack on a police station) or behaved lawfully and within their powers. In these cases, one could expect that the absence of any provocation by the office holder ${ }^{63}$ should be considered an aggravating factor. There are however two reasons why German sentencing practice does not follow this line of reasoning. First, it would mean ascribing an aggravating effect to the pure lack of mitigating factors (namely lack of provocation by the office holder). According to established jurisdiction this is not in line with in German law. ${ }^{64}$ Secondly, where the attack injures not only a police officer but also a civilian bystander, the evaluation of the attack on the office holder as an aggravating factor would mean in comparison that the degree of wrongdoing is lower with regards to civilian victim. ${ }^{65}$ As was shown above, German law does not allow such implied different weighting of persons according to their status. ${ }^{66}$ In other words: the protection of a lawfully acting office-holder cannot call for a more serious penal consequence, as this would imply that a police officer is more valuable than an ordinary citizen. Where the State intends to ensure additional protection of its authorities beyond the general penal law provisions, this is achieved through special provisions such as $\S 113$ (resisting enforcement officers), as well as through offences of state protection ${ }^{67}$ but not through an officially sanctioned increased sentence practice. $^{68}$

The second scenario is where the office-holder has behaved disproportionately in execution of their powers, which means that the offender's actions are at least to some degree understandable, even if the attack does not fulfil the criteria for self-defence. ${ }^{69}$ The question then arises whether the unlawful action of the office-holder, while not justifying the attack, can be at least considered as a mitigating factor at the sentencing stage. In general, it is undisputed in German law that a

\footnotetext{
62 Translation M. Bohlander: German Criminal Code available at http://www.gesetze-iminternet.de/englisch_stgb/englisch_stgb.html (last visited 12 September 2015).

${ }^{63}$ For mitigating effect of understandable but not justifiable motives see Miebach, supra note 45, Rd. 99; Stree, Walter and J. Kinzig in: Schönke and Schröder, above n. 30 at $§ 46$ Rd. 13. Case examples can be found are BGH Strafverteidiger 1982; 1993, 521 and OLG Düsseldorf wistra 1994, 353.

${ }^{64}$ BGHSt 34, 350; BGH Neue Zeitschrift für Strafrecht-Rechtsprechungsreport 2014, 46; Neue Zeitschrift für Strafrecht 2013, 46; Neue Zeitschrift für Strafrecht-Rechtsprechungsreport 2010, 336.

${ }^{65}$ BGH Neue Zeitschrift für Strafrecht-Rechtsprechungsreport 2014, 46.

${ }^{66}$ Both these points were confirmed in the earlier landmark decision by the German Federal Court.

${ }^{67}$ For example high treasons $\S \S 81-83$, blackmailing constitutional organs, §105, or blackmailing the president of the federation and members of constitutional organs $\S 106$.

${ }^{68}$ Whether however in practice courts give higher sentence where the victim is a lawfully acting officer is not known. Empirical research would be welcome to establish whether there is an unofficial sentence practice.

${ }^{69}$ Self-defence in German criminal is defined "Self-defence means any defensive action that is necessary to avert an imminent unlawful attack on oneself or another." $\S 32(2)$.
} 
provocation by the victim, which has been caused by no fault of the offender, counts in favour of the defendant. ${ }^{70}$ In case of a provoking office-holder, the situation must be assessed the same way. It would be therefore impermissible to refuse sentence mitigation only because the victim, who provoked the attack was a police officer.

If the status of the victim as office-holder does not prevent mitigation, it then has to be asked whether sentencing practice should go one step further and whether such a provocation by the office-holder should be considered as a stronger mitigation compared with provocation by a civilian. In favour of this argument, one has to remember that the police officer appears in uniform with the authority of the state and is authorised by law to use force, which is not or not to this degree, granted to civilians. Furthermore, in Germany police officers receive training in techniques of de-escalation and thus are expected to prevent rather than provoke violent behaviour. Moreover, unlike in England, German police are regularly equipped with a service weapon. Last but not least, the police embody the State's claim of the rule of law and thus raise the expectation that all their actions are compliant with the law. For all of these reasons it seems understandable to conclude that where a representative of the State, who epitomises the rule of law, provokes the offender, the officer shares responsibility for the attack which results in a strong mitigating effect. Such line of reasoning must however be rejected due to the earlier mentioned principle of equality between the office-holder and the non-office-holder in matters of legal protection. The wrongdoing against an office-holder does not weigh less, only because the office-holder exercises the executive authority of the State with the necessary powers and resources. In addition, a citizen who is provoked by the disproportionate behaviour of an office-holder in circumstances which do not constitute legal selfdefence, can seek protection through other means short of attacking the police officer. ${ }^{71}$

\section{Comparison}

It is interesting to observe that Germany strongly opposes the idea that the office-holder deserves more protection than ordinary citizens. This is based on the fact that the police force has special training, legal authority and special equipment, which puts them in a stronger position than the offender who feels vulnerable when faced with the force of the law. In England, on the other hand there is the clear understanding that the status of the victim as police officer has a definite effect at the sentencing stage. Thus, the equality between the value of citizen and of police officer, which is so often emphasised in Germany, cannot be found in England. Two things are noticeable: First, this understanding that the wrongdoing is higher when assaulting a police office is not contested but at the same time not articulated, other than only briefly mentioned in the sentencing guidelines' resource statement. Second, while this understanding is generally accepted it contravenes the new sentencing guidelines, which lowers the sentence regarding resistance of an arrest. This discrepancy seems to be rooted in a confusion about which values are to be protected in the relationship between citizen and officer.

\footnotetext{
${ }^{70}$ Schäfer, Sander and Gemmeren supra note 43, Rd. 642. An example of this rule regarding manslaughter can be found in §213, Less Serious Case of Manslaughter. That provocation can be a mitigating factor in non-fatal offences was confirmed by the Federal Supreme Court BGH, decision of 19/06/12, case number 3 StR 206/12. See also T. Fischer, Strafgesetzbuch, 62nd edn (C.H. Beck Verlag: Munich 2015) § 224 Rd. 15.

71 'Fortsetzungsfeststellungklage' (action of declaratory judgement) which is a legal action before the administrative court for the determination of the unlawfulness of a police intervention and the 'Folgenbeseitigungsanspruch' which is a customary claim for claim to remedial action regarding the police encroachment.
} 


\section{Homicide}

In a number of legal systems, the status of the victim as office holder is regarded as an aggravating circumstance in homicide offences. Article 221-4 of the French Penal Code for example prescribes:

The manslaughter is penalised with life imprisonment, if it is committed under the following circumstances:

\section{$[\ldots]$}

Nr. 4: against a judge or prosecutor, a juror, a lawyer, an authenticator or a holder of a public office in administration of justice, a member of gendarmerie, a national police officer, an officer of the custom authorities or the law enforcement administration or against any other person who is owner of public authority or entrusted with a public task in the course or on the occasion of the exercise of their function or the fulfilment of their task, if the position of the victim is obvious or known by the offender. (emphasis added) ${ }^{72}$

In Germany and England on the other hand, there is no separate offence of killing a police officer. As we have seen, in Germany the Federal Supreme Court explicitly rejected the idea that the status of the victim as police officer should make any difference. In England however, unlike in serious non-fatal offences, the sentencing standards for killing a police officer is explicitly dealt with. Section 5(2)(a)Schedule 21 of the Criminal Justice Act 2003 lists "the murder of a police officer or prison officer in the course of his duty" under the cases which require a starting point of 30 years. Interestingly, the same is true for "a murder of two or more persons", which raises the question of whether this implies a law enforcement officer could be considered as worth two civilians! This is of course in direct contrast to the value system in Germany which, as we have seen, does not allow for giving a different weight to different individuals simply based on their status or profession.

Currently, there are proposals in England to increase the tariff for killing a police officer. On May 15, 2013 the Home Secretary Theresa May announced the government proposal to increase the minimum term for killing a police officer from the current 30 years to a compulsory whole life sentence. ${ }^{73}$ Following May's announcement, Justice Secretary Chris Grayling announced in May 2014 that "anyone who kills a police or prison officer in the course of their duty will face spending the rest of their lives behind bars."74 Grayling justifies the increase noting that "police officers play a vital role in keeping communities safe. As has been tragically demonstrated in recent years, this role is a dangerous one which can lead to officers paying the ultimate price while serving their community." 75 There are however voices who suggest that this is a political move trying to smooth the recently strained relationship between the government and the police. Police Federation chairman Steve Williams said that police "morale was low as a result of the government's

\footnotetext{
${ }^{72}$ A similar provision can be found in the new Art. $148 \S 3$ of the Polish Penal Code: "Aggravated homicide is committed by the offender who kills a public official during or in connection with his official duties to protect the safety of persons or the protection of public safety and order” or in the Turkish Penal Code (Art. 82 Abs. 1 g, 86 Abs. 3 c): „Killing or injuring a person who is executing a public office“. All translations by the authors if not otherwise indicated.

${ }^{73}$ BBC news, 'Whole life terms for police killers - home secretary', 15 May 2013 available at http://www.bbc.co.uk/news/uk-22534665 (last visited 12 September 2015).

${ }^{74}$ Ministry of Justice, Press release "Police and prison officer killers to face life in prison” May 2014 available at https://www.gov.uk/government/news/police-and-prison-officer-killers-to-face-life-in-prison (last visited 12 September 2015).

${ }^{75}$ Ibid.
} 
programme of cuts and reforms." ${ }^{76}$ It is however doubtful whether an increased tariff for "cop killers' will cure the recent lack of trust the police seems to have in the government. Danny Shaw, BBC home affairs correspondent, noted that "Theresa May's whole life tariff for police murderers is being welcomed by rank-and-file officers - but it's unlikely to quell the anger felt by Police Federation members about the government's programme of cuts and reforms to the service."77

The discussion was reignited when in October 2014 Harry Roberts, who is now 78, was freed from prison. Harry Roberts had been given three life sentences for killing three unarmed officers in 1966 who had approached Roberts and two others after having been on the run for three months following an armed robbery. This release decision was widely criticised. Although Robert had already served 18 years longer than the 30 years recommended by the judge, the Metropolitan Police Federation called it a "betrayal of policing" as well as a "scandalous, hurtful and abhorrent decision which opens the door even further for those who have scant regard for law and order". ${ }^{7}$ It is however not clear what the door opens to, as it seems rather unlikely that perpetrators are encouraged to attack police officers because Roberts was released after 48 years rather than being imprisoned until his natural death. Does a life sentence without parole increase police protection because of sentencing rationales such as incapacitation? Protection through incapacitation was not mentioned but of course nobody claims that 78 year old Roberts is posing a risk of shooting more police officers. In addition, one must not forget that most killings of police officers are committed while resisting an arrest rather than because of contempt for the police in general. Nevertheless, the London Mayor Boris Johnson claimed that Londoners "will find it hard to understand how a man who shot dead three police officers in this city in the most horrific fashion can now enjoy the freedom he denied his victims". ${ }^{79}$ Not surprisingly, following the decision to release Roberts the Home Secretary once again called for life tariff for officer killers.

To summarise, in England the system of non-fatal offences does not recognise a higher degree of wrong doing when attacking a police officer compared to attacking a civilian. Neither does English law recognise a different offence nor does the Sentencing Guidelines consider the status of the victim as officer an aggravating circumstance. In this regard English law is comparable to German law which does object to the idea that a violent attack is more reprehensible depending on the status of the victim. Nevertheless, in cases of actual or grievous bodily harm, the sentencing practice clearly does make a distinction and it is uncontested that in spite of a lack of explicit sentencing guidelines in this respect even the Sentencing Council recognises that sentences are higher when an officer is attacked. The situation is different in homicide. While we still there is no separate offence in English law, the prescribed sentence clearly distinguishes according to whether the victim was a police officer or not. In the discussion regarding the sentence tariff of officer killings in England we can find some justifications as to why the killing of a police officer is more reprehensible than of an ordinary citizen. In Germany there is no specific legislation, case law or sentencing policy which prescribes a harsher sentence for homicide if the victim is a police officer. We will discuss the different values in the following Section.

\footnotetext{
${ }^{76}$ Above n. 73.

77 Ibid.

${ }^{78}$ BBC news, 'Police killer Harry Roberts to be freed’ 23 October 2014 available at http://www.bbc.co.uk/news/ukengland-29734816 (last visited 12 September 2015).

${ }^{79}$ Ibid.
} 
This article set out to compare German and English criminal law to identify how the State reacts when its police officers are attacked. After having identified the main differences both in the criminal elements as well as in sentencing practice, the final section will discuss the reasons behind these differences. The main question we ask is what exactly the law intends to protect in this area and the justification for this choice.

\section{Protected values in England}

We have seen that in England, the sentencing regime for murder clearly considers the killing of a police officer more seriously than that of an ordinary citizen. Likewise, in non-fatal offences against the person, there seems to be the general notion that harming a police officer will be punished more harshly although this is neither set out in the offences themselves, nor in the sentencing guides. Nor is the assumption discussed in the literature. The question needs to be asked then, why exactly the position of the victim as a police officer is an aggravating circumstance.

One reasons for the special treatment of the police officer when attacked is their vulnerable position. Sir Bernhard Hogan-Howe, MET Commissioner, emphasizes that police officers "deserve the full protection of the law when facing ruthless criminals" ${ }^{80}$ Theresa May justified her request of increasing the tariff with the argument that police officers know "that they might face great danger and they carry out their duties with great courage" ${ }^{81}$ Police officers find themselves in dangerous situations of facing violent criminals on a regular basis but unlike in Germany, in England ordinary police officers do not carry a duty weapon. The argument that the law should give police officers more legal protection because they put themselves in the way of danger in order to protect society begs the question as to why neither in homicide nor in GBH there is a particular offence for cases in which the victim is a police officer.

In addition to the dangerous situation argument, what can also be found is an underlying understanding that the police are the 'good guys' against whom an attack is more reprehensible than against any other citizen. With reference to Harry Roberts' early release, Home Affairs Correspondent at BBC News Tom Symonds commented that "Those who place their lives on the line to protect the public deserve better than this terrible outcome". ${ }^{82}$ This explains why the debate often becomes rather emotional. Boris Johnson, joining the critics of Robert's release, called the decision not simply wrong but "sickening". 83

To what extent an increased sentence offers any protection to the police is however rather questionable. This is especially true with regards to non-fatal offences where the sentence discrepancy is based on practice alone rather than statute or sentencing guidelines. A deterrent effect assumes that the offender not only knows about the higher sentencing practice but also that he or she is aware of it at the time of the attack. The argument that police officers have a dangerous job and therefore deserve more protection does also not compare with other dangerous jobs such as mine workers, construction workers or firefighters. (In Germany the 2011 law reform extended the protection of

\footnotetext{
${ }^{80} \mathrm{P}$. Walker, 'Hogan-Howe joins chorus of anger at release of police killer after 45 years', The Guardian 23 October 2014.

81 Ibid.

${ }^{82}$ supra note 78 .

83 Ibid.
} 
law enforcers in $\S 113$ to members of the fire brigade and emergency and rescue services in $\S 114(\mathrm{III}))$.

While no deterrent effect can be expected, a higher sentence has an important role to play in labelling a certain offence. An example is a life sentence without tariff, which is the highest sentence this country can issue. The labelling effect is important because it reflects the State's explicit message of the role and importance of the police as part of the State. What distinguishes the police officer from other risky professions is that the police represent the State, the community, and the law. First of all, law enforcement is in the interest of the wider public, and condemnation of any interference with the implementation of law and security is therefore justified. Second, an attack on a constable is seen as attack on the Crown upon which every police officer takes their oath. This is especially true in political demonstrations or riots where officers are attacked just for being "part of the system”. A strike against an individual officer is therefore of social significance, which goes beyond the individual harm caused. It is a strike against a fundamental institution. The image of the police as representative as well as member of the community in England is traditionally much stronger than in Germany, as the public perception is still rooted in the concept of policing by consent. This imbedded understanding of the police as part of the community which put themselves in situations of danger to protect this community, explains the informal yet accepted sentence aggravation. More detailed comparative research of the different historical developments of police in England and Germany and their role in state and society would be welcome.

\section{Protected Values in Germany}

Like in England, in Germany it is the protection of the police officer against violent assaults which stands at the core of the public debate. Statistical data suggest that cases of resistance increased by $44 \%$ between 1993 and 2009. Indeed, the sentencing reform in 2011 was mainly justified with the increased number of violent attacks against police officers. ${ }^{84}$ However, critics claim that the increase of assaults can be explained by changes of police operation strategies, such as increased use of force, which provokes citizens to fight back. Another reason for the higher number is that more cases are reported. ${ }^{85}$ Thus, the reason for the increased number of reported incidents lies with the police themselves and this does not require an increase in penalty. In addition, the increase could be the result of a changing notion of what is understood under "resistance" and more importantly changes in the use of discretion of when to charge. ${ }^{86}$

Like in England, reasoning that law enforcers puts themselves in danger of life and limb are regularly repeated and used as an explanation for the increase in the maximum sentence in $2011 .{ }^{87}$ For example Martin Guenther, Senator for Justice in the German State of Bremen is now calling for a minimum sentence to end the practice that offenders are sentenced with a fine only, instead of a custodial sentence. He argues that "persons who are sent by the State into situations of conflict need

\footnotetext{
${ }^{84}$ Compare also the explanations given by the Bundestag in BT-Drs. 17/4143, at 6.

${ }^{85}$ See Singelstein and Puschke, above n. 39 at 3475. For problems of crime statistics in general see H.-D. Schwind, Kriminologie - Eine praxisorientierte Einführung mit Beispielen 21st edn (Kriminalistik: München 2011) § 2 Rd. 4 ff.

${ }^{86}$ Not surprisingly in light of such large discretion, there are large regional differences to be found and some data even note a reduction of incidents from 2009 to 2010 of as much as 12.5\%, J. Puschke, 'Strafverschärfung für Widerstand gegen Vollstreckungsbeamte - ein falsches Signal mit fragwürdiger Begründung' (2012) 1(2/215/216) Mitteilungen der Humanistischen Union. Zeitschrift für Aufklärung und Bürgerrechte 10 at 11 . On the other hand the statistical information is ambiguous as these numbers only count charges under $\S 113$ while injuries will be counted under the statistics for $\S \S 223,224$.

${ }^{87}$ Fischer, above n. 70 at $§ 113$, Rn3.
} 
to be protected by the State" ${ }^{88}$

Again like in England, German scholars too point out that research has shown that the gravity of the sentence has usually no general deterrent effect. ${ }^{89}$ This is especially true in situations of resisting law enforcement where most offenders act without rational deliberation of the consequences of their behaviour (even if assumed they know about the sentence prescribed in the law) ${ }^{90}$ It seems that in Germany as well a substantial part of the justification for the sentencing increase is the message the State intends to send out. The increased sentence was demanded in order to "make explicit that the legislator highly values the protection of state law enforcement acts". ${ }^{91}$ Bremen's Senator for Inner Affairs, Ulrich Mäurer called for a higher sentence because "the attack against the police is also directed against the democratic (Rechtsstaat) State which is represented by the police. He is asking for a "legislative signal". 92

At the same time, $\$ 113$ exposes the tension between the State and civil liberties. The law reform was criticised by some because the legislator gave the police the power to use this offence as a "muzzle". ${ }^{93}$ Critics claim that pre-2011 legislation did sufficiently protect the police officer where injury could be shown, because the general offence of causing bodily harm provides sufficiently severe sentences in case of injury. ${ }^{94}$ The actus reus of $\S 113$ on the other hand, is already fulfilled where an officer as little as pushed. Critics claim that having such a strong charge at their disposal for relatively minor acts of resistance gives the police too much power to ensure submission of citizens. Indeed, according to Joachim Lautensack, Head of the Police Union, most attacks do not happen during political demonstrations and special operations but rather through ordinary daily police service. ${ }^{95}$ As said before, it is doubtful that violent and often drunk offenders, radical demonstrators or football hooligans will be deterred through a sentence increase from two to three years. But it might deter persons who feel being unjustly or unlawfully treated by the police from acting against a seemingly unlawful act, because it is very easy for an officer to threaten with false testimony raising a charge against a citizen. ${ }^{96}$ This is especially true as the assault can be so minor that no external evidence, such as injury or bruise, is necessary.

It seems that in Germany, while the Penal Code originally privileged the defendant who found him or herself vis-à-vis with a law enforcer (both in sentence and mistake regulation), and the Federal Supreme Court emphasises the equality between civilian and police victim, the modern legislator on the other hand focuses now on protection of the police in response to increasing attacks on officers. ${ }^{97}$ It must be asked however whether rethinking policing strategies in violent situations

\footnotetext{
${ }^{88}$ Gewerkschaft der Polizei Bundesvorstand 18.08.2014 available at http://www.gdp.de/id/DE_GdP-Bremen-WerPolizisten-angreift-muss-am-Ende-mit-Gefaengnis-bestraft-werden- (last visited 12 September 2015).

${ }^{89}$ Messer, above n. 28 at 3.

90 Ibid.

${ }^{91}$ M. Stadler, 'Zwischenruf Plädoyer gegen die Einführung eines Sondertatbestands der „Körperverletzung gegen Polizeibeamte”، (2010) Zeitschrift für Rechtspolitik 157.

${ }^{92}$ Gewerkschaft der Polizei Bundesvorstand, above n. 88.

${ }^{93}$ U. Vetter, 'Die Legende von der schutzlosen Polizei' (4.6.2010) lawblog available at http://www.lawblog.de/index.php/archives/2010/06/04/die-legende-von-der-schutzlosen-polizei/ (last accessed October 2015).

${ }^{94}$ Bodily harm can be sentenced up to five years §223, causing bodily harm by dangerous means even up to 10 years $\S 224$.

95 Cornelius, above n. 5.

${ }^{96}$ Vetter, above n. 93.

${ }^{97}$ In 2015 two German states, namely Hessen and Saarland submitted a draft bill to the Bundesrat proposing to create a new offence of "assault against a police officer or representative of State monopoly of force” BR-Drs. 165/15 and BRDrs. 187/1. A critical response can be found in Zöller above n. 36 at 445.
} 
would be more effective in lowering assault incidents rather than a sentence increase.

\section{Final Remarks and Comparison}

It is interesting to see that both criminal justice systems have changed their sentencing regarding resistance against law enforcement in 2011, even though the content and the justifications for the change was quite different in both jurisdictions. While both systems brought the sentencing regime of the lex specialis offence in line with the more general offences, England reduced the sentencing while Germany increased it. In England, the initial aggravating factor of resistance lost its special effect whereas in Germany the original privilege of the offender in an arrest situation was removed. Interestingly, unlike in Germany, in England it was not the legislator who changed the sentencing framework and indeed the change was criticised by the public response to the consultation. Thus, the important value question was decided outside Parliament. This raises questions about the legitimacy and powers of the Sentencing Council which need to be explored elsewhere.

England and Germany clearly differ in their evaluation of the situation where a person is faced with the power of the State. In Germany, the situation of resistance is mitigating, allowing for the vulnerable situation of the offender who is facing the power of the State, while in England it is considered aggravating, due to the inherent attack on the State. One possible reason for the difference could be that in Germany the citizen is potentially more vulnerable than in England because police officers are armed. At the same time, the criminal law and sentencing regime in England ascribes to the police officer a particular worthiness for protection, both because they represent the Crown and because their role exposes them to dangerous situations. The law does therefore not tolerate attacks on officers. In Germany on the other hand, the notion that a police officer deserves more protection than any other ordinary citizen is in principle rejected because it implies qualitative inequality between officer and citizen. Nevertheless the judiciary and many scholars agree that the offence against law enforcement does not only protect the implementation of state power but also the individual. The view that officers are exposed to more violence is reflected in Germany in the debate about rising numbers of assaults against law enforcers in recent years and the latest sentence increase shows a move towards more protection for police through higher sentences. Indeed further increases of sentencing are demanded. ${ }^{98}$ The differences in formal and informal sentencing justifications in the various offences in both England and Germany, show that neither has developed a system which coherently balances the interests of office, officer and citizen.

\footnotetext{
${ }^{98}$ Above n. 6.
} 